\title{
Efektivitas Partisipasi Perempuan Pada Pendidikan Non Formal di Pusat Kegiatan Belajar Masyarakat (PKBM) Kecamatan Wedarijaksa Kabupaten Pati
}

\author{
Abdul Karim \\ Sekolab Tinggi Agama Islam Negeri (STAIN) Kudus \\ akarim_4alp@yahoo.com
}

\begin{abstract}
This study aimed to get an overview of strategies to develop women's participation in non-formal education through the Community Learning Center (Pusat Kegiatan Belajar Masyarakat-PKBM) and the effectiveness of their participation in family and community life. Explorative study used a qualitative approach to obtain field data as well as the clarity of the object that is the focus of the study. The results showed that the effectiveness of women's participation in non-formal education in the PKBM is done through group learning with participatory approaches. The result gives a positive change towards the formation of attitudes and behaviors such as the ability to manage time for activities, foster self-confidence and can provide income.
\end{abstract}

Keywords: Effectiveness, Women's Participation, Non-Formal Education

\begin{abstract}
Abstrak
Penelitian ini bertujuan untuk mendapatkan gambaran strategi mengembangkan partisipasi perempuan pada pendidikan non formal melalui Pusat Kegiatan Belajar Masyarakat (PKBM) serta efektivitas dari partisipasi tersebut dalam kebidupan keluarga dan masyarakat. Penelitian menggunakan pendekatan kualitatif eksploratif untuk mendapatkan data lapangan serta kejelasan terhadap obyek yang menjadi fokus kajian. Hasil penelitian menunjukkan babwa efektivitas partisipasi perempuan pada pendidikan non formal di PKBM dilakukan melalui pembelajaran secara kelompok dengan pendekatan partisipatif. Hasilnya memberikan perubahan positif terhadap pembentukan sikap dan perilaku seperti kemampuan mengelola waktu untuk kegiatan, menumbubkan sikap percaya diri dan dapat memberikan penghasilan.
\end{abstract}

Kata kunci: Efektivitas, Partisipasi Perempuan, Pendidikan Non Formal

Permalink/DOI:http://dx.doi.org/10.18326/infsl3.v11i1.119-140 


\section{Pendahuluan}

Dalam kehidupan masyarakat sering terungkap kasus bahwa perempuan mengalami marjinalisasi dari pergumulan kehidupan sosial. Aktivitas sehari-hari hanya buat kaum laki-laki yang dipahami lebih absah berkarya di luar rumah (ranah publik). Keberhasilan peran laki-laki seringkali tidak menunjukkan bahwa ada keterlibatan peran yang besar dari kaum perempuan, meskipun hanya terbatas dari lingkungan rumah tempat tinggal (ranab domestik). Perempuan lebih dominan ditempatkan untuk menyelesaikan tugas-tugas di lingkungan rumah, sedangkan laki-laki dominan menyelesaikan tugas-tugas di luar rumah (Ihromi, 1990:39). Akibatnya peran perempuan dianggap sebagai pelengkap, tugas yang dilakukan melengkapi tugas laki-laki, sebagai wujud pembidangan ruang lingkup kehidupan keluarga menjadi ranah domestik dan publik (domestik and public domain), perempuan ditempatkan pada ruang kehidupan domestik, sedangkan laki-laki pada ruang kehidupan publik (Siswanto, 1998:48).

Partisipasi perempuan belum mendapatkan apresiasi dari masyarakat bahkan dari lingkungan keluarga sendiri. Hasil kerja dinilai hanya sebatas membantu dan melengkapi pekerjaan yang dihasilkan suami. Sekalipun mendapatkan nilai nominal, tetap saja hasil kerja suami yang diformalisasikan sebagai pekerjaan keluarga. Kondisi ini diperparah dengan pemahaman masyartakat yang umumnya meyakini bahwa penentu kebijakan dan tanggung jawab keluarga hanya ada di tangan suami, meskipun pada kenyataan keberhasilan yang diraih merupakan kerjasama dengan istri.

Partisipasi perempuan dipengaruhi oleh latar belakang pengetahuan, pengalaman serta keterampilan. Makin tinggi kualitas potensi akan semakin baik bentuk partisipasi dalam ikut membina kehidupan keluarga yang pada saatnya akan dapat membangun kemandirian. Sebaliknya pengetahuan dan keterampilan yang terbatas, akan menempatkan peran yang dimiliki perempuan menjadi rendah. Hal ini menjadikan perempuan semakin menyadari perlunya mengembngkan potensinya agar lebih mampu dalam meningkatkan produktivitas kerja (Ulya, 2012:313). 
Ada beberapa pertimbangan, bahwa meningkatkan peran dan partisipasi perempuan mendapat tempat yang signifikan dalam ikut serta membangun masyarakat (social development). Pertama, kebutuhan masyarakat belum semua dapat terpenuhi secara optimal. Melalui partisipasi perempuan diharapkan dapat memberikan kontribusi untuk mengisi dan mengatasi berbagai permasalahan sosial. Antara lain meningkatkan peran kesetaraan gender melalui pendidikan keterampilan tertentu yang dibutuhkan oleh masyarakat dalam konteks pemberdayaan masyarakat guna meningkatkan kualitas hidupnya (Wildan, 2015:229).

Kedua, partisipasi warga dapat memperkokoh solidaritas sosial dan memperkecil jurang pemisah antara berbagai kelompok di masyarakat, seperti kelompok kaya dan miskin, sehingga memperkecil gerakan-gerakan separatis dari kelompok yang "kecewa" maupun pengaruh dari luar yang dapat mengganggu kebersamaan sosial.

Ketiga, partisipasi mendorong masyarakat untuk menciptakan sinergi dan kemitraan dengan pemerintah untuk menciptakan perubahan masyarakat menuju peningkatan kesejahteraan. Partisipasi warga sebenarnya membawa serta prinsip hak azazi manusia, untuk mendapatkan kesempatan melakukan ekspresi diri dalam membangun daerah (Thamrin dan Muhammad, 2002).

Terkait kegiatan pembangunan, partisipasi masyarakat merupakan salah satu jalan menuju kesejahteraan, karena setiap pihak mempunyai hak dan tanggung jawab yang sama, tanpa membedakan lingkungan tempat tinggal. Oleh karena itu masyarakat tidak memandang partisipasi sebagai sebuah kesempatan yang diberikan oleh pemerintah, tetapi layanan dasar yang harus diterima sebagai bagian integral dari local governance, untuk kepentingan menata kehidupan mereka.

Wilayah Kecamatan Wedarijaksa memiliki luas 4.054,71 ha, berpenduduk 56.043 jiwa, dengan komposisi penduduk lakilaki berjumlah 27.812 jiwa dan penduduk perempuan 28.231 jiwa (BPS, 2010). Jumlah penduduk perempuan lebih besar dari pada penduduk laki-laki, apa bila diberdayakan dengan baik, maka kaum 
perempuan akan memiliki arti yang besar bagi peningkatan kualitas kesejahteraan hidup. Pemberdayaan perempuan memiliki manfaat yang signifikan apabila dikaitkan dengan jumlah yang cukup besar. Setidaknya dapat membantu untuk meringankan beban ekonomi melalui produktivitas kerja yang dihasilkan. Partisipasi menjadi peluang untuk melakukan perubahan status keluarga, apalagi dilakukan melalui investasi pendidikan yang dapat memberikan peluang tambahan penghasilan seperti meningkatkan keterampilan lewat pendidikan non formal seperti di Pusat Kegiatan Belajar Masyarakat (PKBM).

Pendidikan non formal PKBM lahir sebagai alternatif keterbatasan sistem penyelenggaraan pendidikan di lembaga pendidikan formal, seperti kurangnya relevansi materi pendidikan dengan kebutuhan masyarakat, kurangnya fleksibilitas, dan pembiayaan maupun kebutuhan sarana-prasarana yang relatif besar (Sudjana, 2004: 38). Menurut Sudjana, penyelenggaraan pendidikan seperti pendidikan keterampilan dipandang memiliki beberapa keunggulan antara lain biaya relatif lebih murah karena program pedidikan dilakukan dalam waktu relatif singkat untuk memenuhi kebutuhan belajar tertentu.

Selain memiliki tingkat relevansi materi pembelajaran, di PKBM program diselenggarakan atas dasar kebutuhan peserta didik, kebutuhan masyarakat dan atau untuk memenuhi kebutuhan lembaga tempat peserta didik bekerja. Terdapat hubungan erat antara isi program pendidikan dengan dunia kerja, kegiatan belajar tidak dipisahkan dari kegiatan bekerja atau kefungsian peserta didik di masyarakat. Program pendidikan non formal memberikan hasil balik yang relatif lebih cepat kepada peserta didik dan lulusannya dibandingkan dengan program pendidikan formal.

Kelebihan pendidikan non formal sebagaimana di PKBM, belum sepenuhnya menjadi program unggulan baik oleh pemerintah maupun lembaga mitra pemerintah seperti lembaga swadaya masyarakat (LSM) atau lainnya, karena beberapa pertimbangan. Pertama, kesulitan menemukan program aksi yang layak menjadi materi pendidikan sekaligus menghasilkan output yang memiliki peluang pasar secara berkelanjutan. Kedua, keterbatasan dana yang 
dapat menjamin ketersediaan modal kerja sebagai tindak lanjut dari implementasi pendidikan. Ketiga, menyangkut kurangnya kesiapan sumber daya manusia baik sebagai peserta didik maupun sebagai fasilitator untuk mendukung terselenggaranya kegiatan pendidikan. Namun, dengan fleksibelitas program, pendidikan di PKBM bisa menjadi alternatif untuk mempersiapkan dan mendorong perkembangan peluang kerja sesuai dengan karakteristik kebutuhan dan kondisi tertentu. Hal tersebut terjadi karena program disesuaikan dengan perubahan kebutuhan peserta didik dan perkembangan lingkungan.

Berdasarkan data monografi (BPS, 2010), penduduk Wedarijaksa bekerja di sektor pertanian lebih dari $50 \%$, terdiri dari $26 \%$ petani dan $28 \%$ sebagai buruh tani. Hal ini menunjukkan bahwa ketergantungan terhadap kondisi alam sangat tinggi sebagai konsekuensi dari bentuk usaha budi daya pertanian. Tinggi rendahnya hasil pertanian berpengaruh besar terhadap upaya meningkatkan kemakmuran keluarga. Perempuan menjadi bagian dari keluarga ikut memiliki tanggung jawab dalam meciptakan kesejahteraan, berkepentingan untuk terlibat dalam usaha produktif. Apa lagi jika melihat jumlah penduduk yangbelum/ tidak memiliki pekerjaan mencapai $23 \%$.

Permasalahannya adalah bagaimana mengembangkan partisipasi perempuan pada pendidikan non formal melalui PKBM serta bagaimanakah efektivitas dari partisipasi tersebut dalam keluarga dan lingkungan sosialnya. Untuk memberikan jawaban perlu kajian peran PKBM sebagai pintu masuk (entry point) untuk melihat seberapa besar kebermaknaan partisipasi perempuan dalam kehidupan keluarga dan masyarakat.

\section{Kajian Pustaka}

Partisipasi menjadi alat ukur untuk mengetahui tingkat perkembangan proses pembangunan masyarakat. Indikator sebagai tolok ukur salah satunya datang dari inisiatif masyarakat sendiri yang merupakan tujuan dari proses pembangunan. Dalam kegiatan pembangunan, partisipasi mengindikasikan adanya dua perspektif (Mikkelsen, 2003), yang pertama, pelibatan masyarakat setempat dalam 
pemilihan, perancangan, perencanaan, dan pelaksanaan program atau proyek yang akan mewarnai hidup mereka, sehingga dapat dijamin bahwa persepsi setempat, pola sikap dan pola pikir serta nilai-nilai dan pengetahuannya ikut dipertimbangkan secara penuh. Kedua, membuat umpan balik (feedback) yang pada hakekatnya merupakan bagian tak terlepaskan dari kegiatan pembangunan.

Partisipasi merupakan proses keterlibatan dalam pembuatan keputusan, pelaksanaan program, memperoleh kemanfaatan, dan mengevaluasi program. Seseorang yang berpartisipasi mengalami keterlibatan dirinya lebih dari sekedar keterlibatan dalam pekerjaan atau tugas saja. Keterlibatan diri berarti keterlibatan pikiran dan perasaan (Hidayat, 2016:16). Artinya, keterlibatan dalam partisipasi dilakukan atas dasar perasaan dan menyetujuai untuk melakukan. Davis (1977:140), memberikan pengertian: "Partisipation is defined as mentalandemotional involvement of person in group situations that encourage to contribute to group goals and share responsibility for them". Partisipasi merupakan bentuk keterlibatan mental dan emosi seseorang untuk mencapai tujuan kelompok serta berbagi rasa tanggung jawab bersama.

Partisipasi memiliki tiga pengertian pokok, yaitu (1) keterlibatan mental emosional, (2) adanya kontribusi, dan (3) tanggung jawab. Dalam implementasi, partisipasi masyarakat dapat berbentuk: memberikan sumbangan berupa sumber daya yaitu, tenaga dan benda yang merupakan bentuk dari kontribusi yang disalurkan; terlibat dalam berbagai usaha penataan dan koordinasi, hal ini menjadi wujud keikutsertaan aspek mental dan pola pikir; serta terlibat langsung dalam penyusunan program dan pelaksanaannya yang merupakan bentuk dari rasa tanggung jawab yang diterima.

Dalam pendidikan partisipatif sering diistilahkan dengan keterlibatan. Makna keterlibatan mengandung ciri-ciri yang hampir sama dengan pengertian yang dikemukakan Davis, yaitu (1) keterlibatan emosional dan mental dari warga belajar yang sedang belajar, (2) adanya kesediaan dari warga belajar untuk memberikan kontribusi dan aktivitas untuk mencapai tujuan, dan (3) dalam kegiatan tersebut terdapat hal yang menguntungkan bagi warga belajar, berupa kepuasan yang ingin dicapai dari tujuan kegiatan tersebut (Knowles, 1970; dan Jahi, 1989). 
Partisipasi hubungannya dengan pendidikan, memberikan kejelasan bahwa terdapat keterlibatan secara menyeluruh aspek lahiriyah dan aspek mental. Kegiatan pendidikan dan pembelajaran yang memberikan kesempatan masyarakat atau warga untuk berpartisipasi, akan memberikan peluang besar dalam mencapai hasil yang diharapkan. Masyarakat atau warga akan mendapatkan motivasi yang besar untuk melakukan kegiatan karena mereka dapat menyampaikan keinginan dan kreativitasnya. Pada akhirnya mereka akan bersedia menerima tanggung jawab untuk mengembangkan baik dalam skala individual maupun bersifat kolektif, karena ikatan untuk menunjukkan keberhasilan dalam meraih tujuan.

Efektivitas partisipasi masyarakat dalam sebuah kegiatan dapat dilihat dari tingkat ketercapaian sesuai dengan tujuan yang telah dirumuskan. Dalam kegiatan yang berbentuk kelompok pengembangan menurut Mikkelsen (2003: 97), memiliki beberapa tujuan antara lain: (1) tujuan utama kegiatan partisipasi adalah agar anggota dapat mengembangkan rencana mereka sendiri, dapat berupa peta kegiatan, atau dokumen yang naratif, sebuah laporan, atau sebuah bagan waktu, yang kesemuaya dihasilkan oleh para peserta sendiri melalui proses pendapimngan; (2) berkaitan dengan kegiatan proyek, partisipasi bertujuan untuk menciptakan dialog di kalangan para 'stakeholder' termasuk fasilitator guna memperoleh informasi yang diperlukan melalui komunikasi yang sesuai.

Suryadi (1974:79) berpendapat, implementasi prinsipprinsip pendidikan partisipatif mencakup prinsip kebutuhan, integral, terpadu, berkelanjutan, kemampuan sendiri, dan kaderisasi. Prinsip kebutuhan, memiliki pengertian bahwa setiap kegiatan pengembangan program kegiatan kelompok, termasuk kelompok belajar seharusnya berdasarkan kepada permasalahan serta kebutuhan. Kegiatan pemberdayaan kelompok belajar bermula dari kebutuhan yang dirasakan serta bersifat mendesak, seterusnya mengarah kepada kebutuhan yang diharapkan oleh kelompok belajar untuk masa mendatang. Program-program kegiatan kelompok belajar dalam penyusunannya dilandasi oleh kebersamaan dan untuk kepentingan kelompok belajar. 
Prinsip integral, memiliki pengertian bahwa aktivitas kehidupan kelompok belajar seyogyanya meliputi seluruh aspek kehidupan kelompok, baik yang berkaitan dengan aspek material dari anggota kelompok dan juga yang berkaitan erat dengan aspek mental spiritual. Dengan terjadinya keseimbangan antara kebutuhan yang dirasakan dengan yang dinyatakan oleh anggota kelompok belajar, akan dapat memacu kelompok untuk lebih berdaya.

Berkaitan dengan prinsip keterpaduan, bahwa program kegiatan kelompok belajar selayaknya mampu berperan untuk memenuhi berbagai pihak yang berkepentingan (stakeholder) (seperti pemerintah, pembelajar, dan keluarganya). Akan sangat bijaksana apabila suatu program kegiatan kelompok belajar dikembangkan melalui pemaduan top-down dengan bottom-up. Keterpaduan yang dimaksud akan tercermin pada langkah-langkah dalam pengembangan program kegiatan pembelajaran, yaitu dalam perencanaan, pelaksanaan, maupun dalam penilaian.

Prinsip keberlanjutan, yang memiliki pengertian bahwa kegiatan, pemberdayaan kelompok belajar tidak terjadi sekaligus, akan tetapi merupakan proses yang berlangsung terus menerus (on-going process), yang bergerak kearah ke-keberdayaan kelompok belajar. Jadi, upaya untuk menuju ke-keberdayaan kelompok sematamata bukan merupakan usaha yang bersifat insidental, akan tetapi merupakan kegiatan yang direncanakan diwaktu-waktu mendatang.

Prinsip kemampuan sendiri, diartikan bahwa program kegiatan kelompok belajar dalam perencanaannya bertitik tolak dari kemampuan kelompok belajar. Untuk itu perlu difahami komposisi latar belakang anggota kelompok belajar, fasilitas penunjang, lingkungan fisik dan sosial, maupun dukungan dari lembagalembaga yang berkepentingan. Dengan kata lain, perlu dilakukan penggalian dan pendayagunaan sumber-sumber yang tersedia dan pemanfaatannya secara efektif dalam upaya memberdayakan kelompok belajar.

Prinsip yang tidak kalah pentingnya dalam memberdayakan kelompok belajar adalah kaderisasi. Prinsip ini memiliki makna bahwa upaya pengelolaan kelompok belajar dan untuk kontinyuitas kehidupan kelompok belajar yang lebih baik, apabila di dalam 
kelompok belajar telah dipersiapkan kader-kader kelompok yang memiliki sikap, pengetahuan, dan keterampilan untuk memberdayakan kelompok belajar.

Terkait pendidikan keterampilan, untuk menciptakan dan mengembangkan kondisi pembelajaran partisipatif, Knowles (1970: 269-292) mengemukakan langkah-langkah yang perlu ditempuh, yaitu; (1) menciptakan suasana belajar agar anggota kelompok siap untuk melakukan kegiatan belajar; (2) membantu anggota kelompok untuk menyusun kelompok agar anggota kelompok melakukan saling belajar; (3) membantu anggota kelompok dalam mendiagnosis kebutuhan belajar; (4) membantu anggota kelompok dalam menyusun tujuan belajar; (5) membantu anggota kelompok merancang pola-pola pengalaman belajar; (6) membantu anggota dalam melakukan kegiatan belajar; (7) membantu anggota kelompok dalam melakukan evaluasi terhadap hasil dan proses kegiatan belajar.

Tahapan yang memperkuat partisipasi adalah membantu kelompok melakukan kegiatan belajar antara lain dengan (1) penyajian bahan belajar dilakukan melalui dialog, seminar, demonstrasi, dan Iain-lain; (2) teknik partisipasi dalam kelompok, seperti melalui forum, tanya jawab, maupun kelompok pendengar; (3) teknik simulasi, seperti bermain peran, dan kasus; dan (4) teknik latihan keterampilan (Sudjana, 1993: 157).

Dalam mengevaluasi hasil dan proses belajar, peserta belajar mencocokkan antara kemampuan yang telah dimiliki dan hasil pembelajaran dengan kebutuhan pembelajaran yang diharapkan, dengan teknik self-evaluation, seperti melalui diskusi, lembaran pendapat, maupun deskripsi interpretasi. Sementara untuk mengevaluasi proses kegiatan pembelajaran diarahkan untuk mendiagnosis tingkat kesesuaian antara kebutuhan belajar dan rencana kegiatan belajar serta melihat jarak perbedaan antara kemampuan pada saat ini dengan kemampuan yang diharapkan.

Pengaruh hasil belajar partisipatif terhadap kehidupan dapat dilihat dari aspek perubahan taraf hidup, meningkatnya tingkat partisipasi anggota kelompok, dan meningkatnya kegiatan pemberdayaan masyarakat. Hasil penelitian Hajaroh (2014), 
menunjukkan bahwa, keterlibatan dan partisipasi dalam kelompok akan membawa perubahan, tidak saja bersifat kuantitatif, seperti berkembangnya wawasan dan pengetahuan, sikap serta keterampilan memberdayakan diri maupun kepada masyarakat sekitar (Hajaroh dan Sungkowo, 2014:32).

Hasil akhir yang diperoleh dari belajar partisipatif dapat membentuk kemandirian. Demikian juga orientasi berpikir berdasar pada pengalaman dan potensi serta keterampilan, akan mengantarkan pada pengembangan diri berdasarkan pemahaman dan kesadaran terhadap potensi yang dimiliki kearah terciptanya sikap hidup yang kreatif dan bertanggung jawab, tidak hanya menggantungkan pada pihak lain untuk meraih keberhasilan. Kesuksesan adalah sebuah prestasi dari hasil perjuangan atas dasar kemauan dan potensi diri, bukan semata hadiah atau pemberian dari orang lain.

\section{Metode Penelitian}

Penelitian ini menggunakan pendekatan kualitatif eksploratif, dengan memperhatikan "karakteristik alami (natural setting), sehingga proses lebih dipentingkan daripada hasil, analisis dalam penelitian kualitatif cenderung dilakukan secara analisa induktif, dan makna merupakan hal yang esensial" (Moleong, 2000:3). Jenis eksplorasi dimaksudkan untuk mencari kejelasan terhadap obyek langsung melalui penjelajahan dengan grant tour quertion (Sugiyono, 2005: 22). Selain wawancara mendalam (indept interview) penelitian dilakukan melalui deskripsi intensif dan analisis fenomena tertentu atau satuan sosial seperti individu, kelompok, institusi atau masyarakat yang berkaitan dengan fokus penelitian, sehingga permasalahan akan dapat ditemukan secara jelas.

Lokasi penelitian mengambil kegiatan pendidikan non formal pada Pusat kegiatan Belajar masyarakat (PKBM) Wedarijaksa Kabupaten Pati. Peserta kegiatan terdiri kaum perempuan berasal dari pedesaan di wilayah Kecamatan Wedarijaksa. Masyarakat memiliki kultur transisi menuju masyarakat maju dari semula yang masih terikat nilai-nilai tradisional berbasis kearifan lokal.

Sumber data penelitian diambil dari representasi dari peserta 
didik kegiatan pendidikan non formal yang mencerminkan dari karakteristik pedesaan daerah tersebut. Strategi pengambilan data seperti itu mengingat adanya perbedaan latar belakang sosial budaya (setting social) dari masing-masing daerah, sehingga diharapkan kelengkapan informasi dapat dicapai sesuai kebutuhan penelitian.

Analisa data dilakukan melalui proses pelacakan dan pengaturan secara sistematik dari transkip wawancara, catatan lapangan dan bahan-bahan lain yang dikumpulkan untuk meningkatkan pemahaman (Bogdan, 1982). Analisis dimulai sebelum memasuki lapangan, dilakukan terhadap data hasil studi pendahuluan, atau data sekunder yang akan digunakan untuk menentukan fokus penelitian. Analisis selama di lapangan dilakukan pada saat pengumpulan data berlangsung. Kegiatan analisis selanjutnya adalah reduksi data (data reduction), display data (data display), dan penarikan kesimpulan (conclusion drawing/verification) (Sugiyono, 2005: 90). Reduksi data dilakukan untuk merangkum, memilih hal-hal yang pokok dari data-data yang terkumpul, kemudian memfokuskan pada hal-hal yang penting, kemudian dicari tema dan polanya, sehingga diperoleh gambaran lebih jelas dan mempermudah pengumpulan data lebih lanjut. Display data dilakukan dalam bentuk uraian singkat, bagan, hubungan antar kategori dan sejenisnya melalui teks yang bersifat naratif, untuk mempermudah dalam memahami apa yang terjadi. Sedangkan tahap berikutnya adalah penarikan kesimpulan dan verifikasi berdasarkan bukti-bukti yang valid sampai diperoleh kesimpulan akhir yang valid dan kredibel. Untuk mendapatkan kesahihan (validitas) dan keandalan data (reliabilitas), dilakukan dengan teknik (1) pengamatan yang tekun, dan triangulasi yang memanfaatkan sumber yang lain di luar data yang diperoleh, untuk keperluan pengecekan atau sebagai pembanding (Moleong, 2000:171).

\section{Pembahasan}

Pusat Kegiatan Belajar Masyarakat (PKBM), merupakan salah satu tempat menyalurkan partisipasi perempuan di bidang pendidikan keterampilan. Lembaga ini dibentuk dari, oleh dan untuk 
masyarakat. Ini berarti PKBM merupakan suatu institusi yang berbasis masyarakat (Community based Institution). Pendirian PKBM merupakan inisiatif dari masyarakat itu sendiri yang datang dari suatu kesadaran akan pentingnya peningkatan mutu kehidupannya melalui suatu proses-proses transformasional dan pembelajaran. Dalam hal pendirian PKBM peran pemerintah ataupun pihak lain di luar komunitas tersebut hanyalah berupa proses sosialisasi, motivasi, stimulasi dan pelatihan untuk memperkenalkan PKBM secara utuh dan membuka perspektif serta wawasan dan langkah-langkah yang dapat dilakukan dalam pengembangan selanjutnya.

Penyelenggaraan dan pengembangan serta keberlanjutan PKBM sepenuhnya menjadi tanggungjawab masyarakat itu sendiri. Ini juga bermakna adanya semangat kemandirian dan kegotongroyongan dalam penyelenggaraan PKBM. Dengan kata lain, penyelenggaraan PKBM tidak harus menunggu kelengkapan ataupun kecanggihan sarana dan prasarana yang dimiliki oleh suatu masyarakat. PKBM dapat saja berlangsung dalam kesederhanaan apapun yang dimiliki oleh suatu masyarakat. Penyelenggaraan PKBM didasarkan dan memperhatikan potensi yang dimiliki oleh suatu masyarakat.

Untuk masyarakat dimaksudkan keberadaan PKBM sepenuhnya untuk kemajuan kehidupan masyarakat. Itu berarti, pemilihan program-program yang diselenggarakan di PKBM benarbenar sesuai dengan kebutuhan masyarakat setempat. Di luar anggota masyarakat setempat bisa turut serta mengikuti berbagai program dan kegiatan yang diselenggarakan oleh PKBM, sepanjang tidak menghambat pemberian manfaat bagi masyarakat sekitarnya. Prioritas dan fokus pemberdayaan tentunya harus tetap tertuju kepada masyarakat sasaran PKBM itu sendiri. Masyarakat bertindak sekaligus sebagai subyek dan obyek dalam berbagai kegiatan yang diselenggarakan oleh PKBM.

Kegiatan PKBM dikelompokkan dalam tiga bidang kegiatan, yaitu bidang kegiatan pembelajaran (learning activities), bidang kegiatan usaha ekonomi produktif (business activities) dan bidang kegiatan pengembangan masyarakat (community development activities). Kegiatan pembelajaran memasukkan semua kegiatan 
yang merupakan proses pembelajaran bagi anggota komunitas dan berupaya melakukan transformasi kapasitas, kemampuan, kecerdasan intelektual, emosi dan spiritual, watak dan kepribadian meliputi aspek kognisi, afeksi dan psikomotorik. Pembelajaran juga mencakup seluruh kalangan baik dari usia dini sampai lanjut usia, pria dan wanita, seperti program pendidikan anak usia dini, program pendidikan kesetaraan (Paket A, B, dan C), pendidikan mental spiritual, pendidikan keterampilan dan masih ada program pendidikan yang lain.

Kegiatan usaha ekonomi produktif mencakup semua kegiatan yang berkaitan dengan upaya peningkatan pemberdayaan ekonomi anggota komunitas. Di dalamnya mencakup programprogram antara lain kelompok belajar usaha, pengembangan usaha warga, kerjasama dan jaringan usaha masyarakat serta upaya-upaya peningkatan produktivitas masyarakat. Sedangkan kegiatan pengembangan masyarakat mencakup berbagai kegiatan dalam rangka penguatan kapasitas komunitas tersebut sebagai suatu kelompok. Di dalamnya mencakup berbagai jenis seperti penguatan sarana/prasarana/infrastruktur baik fisik maupun non fisik, penguatan kohesivitas di antara masyarakat, perbaikan dan pengembangan lingkungan, serta penggalian, pengembangan dan pembudayaan bahasa dan budaya asli komunitas tersebut.

\section{Partisipasi Perempuan}

Partisipasi perempuan di PKBM dapat dilihat dari kualitas dan kuantitas partisipasi mereka dalam kegiatan perencanaan, penyelenggaraan maupun pengembangan PKBM di antaranya partisipasi pada pendidikan keterampilan. Semakin tinggi jumlah anggota masyarakat yang berpartisipasi dalam kegiatan PKBM maka semakin tinggi keberhasilan PKBM. Demikian juga semakin tinggi keterlibatan perempuan dalam kegiatan PKBM menggambarkan semakin besar manfaat PKBM bagi perempuan dan masyarakat. Tingkat partisipasi pada PKBM, dapat dilihat pada setiap proses manajemen, baik dalam perencanaan, pengorganisasian, pelaksanaan dan pengendalian berbagai kegiatan. Partisipasi perempuan dan masyarakat juga dapat ditunjukkan melalui dukungan dalam 
keterlibatan kegiatan, penyediaan sarana dan prasarana, dana, tenaga personalia, masukan ide/gagasan, dan sebagainya.

Bentuk partisipasi perempuan salah satunya mengikuti pendidikan keterampilan, yang menjadikan sebagai peluang kegiatan yang dapat mendatangkan penghasilan. Keikutsertaan ini ditempuh karena beberapa alasan. Pertama, tuntutan kebutuhan keluarga yang semakin besar, sementara tingkat penghasilan yang didapat oleh anggota keluarga lain seperti suami, anak atau saudara belum mencukupi. Kedua, desakan keinginan untuk mengembangkan wawasan, agar tidak ketinggalan pengetahuan dan informasi tentang perkembangan lingkungan. Ketiga, menambah jaringan komunikasi dengan masyarakat, sehingga dapat menambah teman untuk saling tukar informasi.

Pendidikan keterampilan berbasis partisipasi, mencakup dua kegiatan utama yang meliputi kegiatan persiapan, dan pelaksanaan. Kegiatan persiapan pembelajaran diperlukan untuk mengkoordinasikan komponen-komponen sistem pembelajaran, yaitu tujuan, bahan/materi, strategi atau metode, media, dan evaluasi. Kegiatan persiapan sedikitnya mencakup tiga kegiatan utama yaitu; (1) identifikasi kebutuhan, (2) perumusan tujuan belajar, dan (3) penyusunan program pembelajaran.

Identifikasi kebutuhan dimaksudkan untuk melibatkan dan memotivasi peserta didik agar kegiatan belajar dirasakan sebagai bagian dari kehidupan sehingga mereka merasa memiliki. Proses ini dilakukan dengan mengidentifikasi kesenjangan tingkat pengetahuan yang saat itu sedang dikuasai dengan standar materi yang harus dikuasai sesuai tujuan yang ditetapkan. Perbandingan antara materi dan pengetahuan yang telah dikuasai dengan standar materi yang menjadi tujuan pembelajaran merupakan kebutuhan materi pembelajaran dari peserta didik.

Perumusan tujuan merupakan hasil analisis kebutuhan untuk menjadi acuan merumuskan tujuan pembelajaran. Dalam merumuskan tujuan, mengacu pada rumusan tujuan pendidikan nasional dan tujuan pendidikan non formal sebagai bentuk tujuan ideal yang akan dicapai. Tujuan pendidikan nasional yang tertuang dalam pasal 3 Undang-Undang Nomor 20 tahun 2003 tentang 
Sistem Pendidikan Nasional (SPN) berbunyi "Pendidikan nasional bertujuan mengembangkan potensi peserta didik agar menjadi manusia yang beriman dan bertakwa kepada Tuhan Yang Maha Esa, berakhlak mulia, sehat, berilmu, cakap, kreatif, mandiri, dan menjadi warga negara yang demokratis serta bertanggung jawab".

Terkait dengan tujuan pendidikan non formal seperti ditulis dalam Undang-Undang Nomor 20 tahun 2003 pasal 26 disebutkan bahwa, "Pendidikan non formal berfungsi mengembangkan potensi peserta didik dengan menekankan pada penguasaan pengetahuan dan keterampilan fungsional serta pengembangan sikap dan kepribadian profesional".

Pendidikan keterampilan berbasis partisipasi di PKBM memiliki kekhususan antara lain peserta didik semua terdiri dari orang dewasa. Keterikatan dalam proses belajar karena keinginan untuk meningkatkan keterampilan yang diperlukan untuk memenuhi kebutuhan hidup. Secara operasional rumusan tujuan pembelajaran merujuk pada pengembangan lima aspek yakni partisipasi, pengetahuan, nilai-nilai, keterampilan, dan kesadaran. Aspek partisipasi mengembangkan semuanya baik individu, kelompok, dan masyarakat sebagai peserta didik untuk mengembangkan peran sertanya melalui keterampilan.

Dari segi nilai, pendidikan keterampilan membantu untuk mengembangkan rasa peduli terhadap berbagai macam isu agar dapat mengambil kebijakan guna mempromosikan upaya meningkatkan kemandirian. Aspek keterampilan, membantu meningkatkan kompetensi atau keterampilan berkarya, agar mampu mengidentifikasi dan mengantisipasi permasalahan ekonomi dan sosial, sehingga dapat menyelesaikan dan mengurangi sikap ketergantungan. Sedangkan dari aspek kesadaran, pengetahuan itu semua dapat berdampak positif terhadap perilaku dan gaya hidup (life style) dalam jangka pendek maupun jangka panjang untuk membangun kemandirian.

Penyusunan program pembelajaran memberikan arah kepada pencapaian tujuan berdasarkan hasil pemilihan kebutuhan peserta didik. Suatu program pembelajaran akan membedakannya dengan yang lain berdasarkan materi yang disusun mengikuti kompetensi 
atau keterampilan yang telah ditetapkan. Keputusan memilih materi berdasarkan kompetensi akan ikut menentukan kegiatan apa yang akan dilakukan untuk mencapai tujuan oleh kelompok belajar, sehingga program pembelajaran itu menjadi konkrit dalam pengembangan selanjutnya.

Tahap penyusunan program kegiatan belajar rnencakup komponen program kegiatan belajar dan proses pelaksanaan program. Komponen program mencakup bahan materi belajar, metode dan teknik, fasilitas dan sarana belajar, waku belajar dan daya dukung lainnya. Program kegiatan belajar terdiri atas komponenkomponen yang saling berhubungan serta berinteraksi antara satu dengan lainnya dan memuat langkah-langkah pelaksanaannya.

Untuk merealisasikan perencanaan program yang bersifat partisipatoris, dilakukan beberapa tindakan seperti (1) memberikan penjelasan kepada kelompok mengenai tujuan program beserta indikator-indikatornya; (2) bila terdapat beberapa tujuan, dilakukan penilaian menurut prioritas tujuan oleh semua anggota; (3) mengadakan pertemuan membahas hasil prioritas dan memberikan pertimbangan-pertimbangan serta memutuskan tujuan dan indikatornya; (4) meyakinkan kebenaran program untuk merealisasikan tujuan melalui pendapat pihak lain seperti para ahli, akademisi, dan tokoh masyarakat untuk dijadikan bahan pertimbangan perbaikan program; (5) program dengan tujuan dan beberapa pertimbangan dilaporkan kepada pimpinan program.

\section{Pendidikan Keterampilan}

Pendidikan keterampilan berbasis partisipasi dilakukan berdasarkan langkah-langkah yang telah dirumuskan dalam perencanaan yang meliputi mengidentifikasi kebutuhan pembelajaran, merumuskan tujuan, dan penyusunan materi pembelajaran. Pelaksanaan merupakan implementasi keseluruhan proses belajar yang direncanakan. Dalam hal ini materi, metode, sarana belajar dan waktu yang diperlukan ditetapkan sesuai dengan kebutuhan pendidikan keterampilan, sehingga peserta didik memperoleh kesempatan dan pengalaman belajar yang optimal. 
Membentuk kelompok belajar merupakan salah satu strategi pembelajaran sebelum pendidikan dimulai yang bertujuan untuk meningkatkan partisipasi peserta didik melalui komunikasi edukatif. Proses komunikasi dapat terbentuk lebih efektif melalui kelompokkelompok belajar yang jumlahnya tidak terlalu besar. Pembentukan kelompok dapat diklasifikasikan mulai dari skala kecil, sedang dan kelompok besar. Jenjang kelompok didasarkan atas keluasan dan berat-ringannya tugas-tugas yang akan dijalankan oleh anggota kelompok, baik dalam proses pembelajaran maupun di lapangan.

Selanjutnya dilakukan pembinaan dengan maksud agar proses belajar bersama antar peserta didik melalui kelompok dapat saling memberikan informasi untuk mengembangkan materi keterampilan dengan dipandu oleh fasilitator, sehingga partisipasi menjadi berkembang. Untuk mengembangkan partisipasi dilakukan langkah-langkah pertama, belajar mengacu pada kebutuhan, yakni keinginan maupun kehendak yang dirasakan oleh orang peserta didik, baik berupa pengetahuan, keterampilan, dan sikap. Kedua, kebutuhan belajar didasarkan pada usaha pencapaian tujuan yang sebelumnya telah ditetapkan. Penetapan tujuan belajar yang dimaksud merupakan kesepakatan bersama antara peserta didik dengan nara sumber belajar atau fasilitator.

Ketiga, dalam kegiatan belajar mengacu dari kondisi riil kehidupan, seperti kondisi ekonomi, sosial, pendidikan, dan pekerjaan. Oleh karena itu peserta didik berperan serta dalam mengidentifikasi permasalahan serta kebutuhan-kebutuhan mereka sendiri. Keempat, kegiatan belajar dilakukan mengacu pada pengalaman yang telah dimiliki anggota kelompok, sehingga hasil pendidikan lebih berdaya guna.

Dalam proses pendidikan, kelompok belajar dijadikan sebagai metode sekaligus sebagai media untuk melakukan perubahan. Model pendidikan keterampilan seperti ini bisa dikatakan berhasil, karena adanya partisipasi aktif peserta didik. Pendidikan keterampilan partisipatif di PKBM memiliki keunikan tersendiri, karena selain menguasai keterampilan, juga disosialisasikan kepada anggota kelompok tentang pembentukan etika dalam hidup berkelompok. Etika sosial bisa dibentuk melalui pertama, mengembangkan 
kesadaran dan perhatian terhadap kondisi ekonomi, sosial, politik, dan saling ketergantungan, di saat yang sama masyarakat diajak memahami dan menyadari bahwa keharmonisan lingkungan sosial yang menjadi sandaran hidup, tergantung pada sikap serta perilaku mereka. Kedua, memberikan peluang masyarakat untuk mengembangkan pengetahuan dan keterampilan yang dibutuhkan untuk hidup berkelompok. Masyarakat mendapatkan informasi untuk memperoleh berbagai pengalaman guna mengubah pola hidup melalui pendidikan yang memuat nilai-nilai esensial yang bermanfaat bagi kehidupan. Ketiga, menciptakan pola perilaku baru baik individu, kelompok, ataupun masyarakat secara keseluruhan, dengan menumbuhkan kesanggupan menemukan bersama berbagai solusi atas permasalahan sosial yang muncul.

\section{Efektivitas Partisipasi}

Pendidikan keterampilan perempuan di PKBM menekankan pada pemberdayaan, hasilnya dapat mengubah sikap dan perilaku serta kemampuan berproduksi. Pertama, perempuan mampu menunjukkan sikap mengontrol kehidupannya. Hal ini diperlihatkan dengan keterlibatannya secara kelompok dalam menyusun perencanaan kegiatan di PKBM. Keikutsertaan dalam perencanaan dapat memberikan pengaruh terhadap pengaturan waktu untuk membagi peran guna kepentingan keluarga, pendidikan dan untuk kepentingan masyarakat. Disiplin waktu berpengaruh terhadap etos kerja yang sebelumnya kurang ada pengendalian dalam penggunaan waktu menjadi teratur dan tidak banyak melewatkan waktu sia-sia, sehingga mendorong peningkatan produktivitas kerja.

Kedua, perempuan dapat menentukan agenda kegiatannya, melalui proses identifikasi kegitan dan kebutuhan dengan berbagai pertimbangan, seperti melakukan prioritas kegiatan mana yang harus didahulukan sesuai kebutuhan. Penentuan jenis kebutuhan dan kegiatan memberikan dampak positif terhadap sikap kemandirian serta tanggung jawab dari pilihan tindakan yang telah diambil. Tindakan seperti itu apabila dilakukan secara berulang-ulang, akan menumbuhkan kebiasaan (habituation) yang dapat membentuk sikap dan perilaku berani mengambil tindakan dari permasalahan 
yang muncul serta alternatif pemecahan masalah yang diperlukan.

Ketiga, perempuan dapat mengembangkan keterampilan secara optimal sebagai dampak pilihan kegiatan yang diambil. Pilihan kegiatan berupan pendidikan keterampilan, yang memberikan dampak positif terhadap maksimalisasi pengembangan bakat dan potensi. Seperti kelompok binaan di pedesaan, misalnya di Desa Swaduk yang mengembangkan keterampilan membuat keset dari kain kilon. Di Desa Tluwuk menghasilkan bandeng presto dan menghasilkan baki, tempat kue lamaran terbuat dari bahan rotan yang ditekuni oleh kelompok dari Desa Bumiayu.

Keempat, perempuan mampu menumbuhkan kepercayaan pada kemampuan diri sebagai hasil pilihan kegiatan yang telah mampu memberikan kontribusi bagi kebutuhan ekonomi keluarga. Kemampuan memberdayakan potensi memberikan penilaian yang kuat terhadap kelompok serta masyarakat sekitar bahwa mereka memiliki sumbangan yang berarti bagi kesejahteraan keluarga dan warga masyarakat dalam ikut serta meningkatkan pembangunan ekonomi warga.

Keberhasilan pendidikan keterampilan perempuan di PKBM tidak hanya terbatas pembentukan sikap dan moral anggota kelompok yang lebih baik, namun juga dapat menghasilkan uang, sehingga memberikan perubahan kepuasan secara material meskipun masih dalam jumlah yang belum besar.

Tabel 1.

Keberhasilan Partisipasi Perempuan pada Pendidikan Keterampilan Di PKBM Wedarijaksa Pati

\begin{tabular}{llll}
\hline $\begin{array}{l}\text { Kelompok } \\
\text { Belajar }\end{array}$ & \multicolumn{2}{l}{ Jenis Keterampilan } & Keberhasilan \\
\hline Desa Swaduk & $\begin{array}{l}\text { Keset dari kain } \\
\text { kilon }\end{array}$ & $\begin{array}{l}\text { Setiap anggota mendapatkan } \\
\text { penghasilan Rp 60.000,- s/d Rp } \\
200.000,-/ \text { minggu }\end{array}$ \\
Desa Tluwuk & Bandeng Presto & $\begin{array}{l}\text { Setiap anggota mendapatkan } \\
\text { penghasilan Rp 50.000,- s/d Rp } \\
100.000,-/ \text { minggu }\end{array}$ \\
& & 100
\end{tabular}


Desa Bumiayu Baki rotan tempat Setiap anggota mendapatkan kue lamaran penghasilan Rp 50.000,- s/d Rp 100.000,-/minggu

Sumber: Hasil analisis dari data-data lapangan

Beberapa kelompok yang lain masih belajar keterampilan tahap permualaan, sehingga belum menampakkan hasil yang layak dipasarkan. Masih butuh pendampingan secara berkala untuk dapat mencapai hasil keterampilan yang layak jual.

Kenyataan di lapangan menunjukkan bahwa, keinginan dari masyarakat untuk berpartisipasi pada program-prgram PKBM masih belum optimal karena beberapa alasan. Pertama, rendahnya pendidikan dan pengalaman, sehingga manfaat yang akan dihasilkan kurang dipahami dengan baik. Hal ini menjadikan sikap kurang percaya diri terhadap kegiatan pendidikan keterampilan yang diselenggarakan.

Kedua, keterbatasan kemampuan petugas dari aspek metodologi, seperti fasilitator dan para pengurus PKBM yang mendampingi kelompok masyarakat dalam memberikan bimbingan dan penyuluhan. Ketiga, belum ada dukungan kuat dari pihak pemerintah untuk menyediakan materi atau kurikulum pendidikan, demikian juga sarana dan prasarana yang dibutuhkan. Dan keempat, masyarakat memiliki keinginan untuk mempercepat diri merubah kehidupan melalui pemenuhan kebutuhan yang belum sepadan dengan tingkat pendapatan yang diperoleh, sehingga muncul sikap enggan mengikuti pendidikan dengan lebih giat.

\section{Kesimpulan}

Pendidikan keterampilan perempuan di PKBM Wedarijaksa dapat memberikan hasil perubahan positif terhadap pembentukan sikap dan perilaku, seperti kemampuan mengelola waktu dan kegiatan serta menumbuhkan sikap percaya diri. Keberhasilan seperti itu dilakukan melalui pembelajaran secara kelompok dengan pendekatan partisipatif serta pendidikan keterampilan dapat memberikan penghasilan yang nyata. Hal ini menunjukkan 
perempuan memiliki peluang beraktivitas tidak terbatas pada sektor domestik saja, akan tetapi dapat juga di sektor publik.

\section{Daftar Pustaka}

Bogdan dan Biklen, 1982. Qualitative Research for Education, An introduction to theory and methods. Boston: Allyn and Bacon.

Davis, K. (1977). Human Behavior At Work, Organizational Behavior. New York: Mc Graw-Hill, Inc.

Hajaroh, Laela dan Sungkowo Edy Mulyono, 2014. Partisipasi Anggota Kelompok Swadaya Masyarakat Dalam Pengembangan Desa Wisata Melalui Badan Keswadayaan Masyarakat Di Kelurahan Kandri Kota Semarang. Journal of Non Formal Education and Community Empowerment. http://journal.unnes.ac.id/sju/ index. php/jnfc. NFECE 3 (2) (2014). ISSN 2252-6331.

Hidayat, Dayat, 2016. Strategi Pembelajaran Partisipatif dalam Meningkatkan Hasil Program Pendidikan Non Formal di Kabupaten Karawang. Journal of Nonformal Education. http:// journal.unnes.ac.id/ nju/index. php/jne. Vol.2 No 1, Tahun 2016. ISSN 2442-532X.

Ihromi, T. O. 1990. Wanita Bekerja Dan Masalah-Masalahnya. Dalam Toeti Heraty Noerhadi. Ed. Dinamika Wanita Indonesia. Jakarta : Pusat Pengembangan Sumberdaya Wanita ( PPSW ).

Inayatul Ulya, 2012. Pendidikan Berbasis Kesetaraan Gender (Studi Kebijakan Pemerintah dan Aplikasinya dalam Pendidikan), Jurnal Islamic Review, Jurnal Riset dan Kajian Keislaman, Vol. I No. 2 Oktober 2012 (309-336), ISSN: 2089-8142.

Jahi, A. (1989). Penyuluhan Pembangunan Peternakan. Bogor: Jurusan Sosial Ekonomi Peternakan, Fakultas Peternakan Institut Pertanian Bogor.

Kabupaten Pati Dalam Angka 2010, Bappeda dan BPS Kabupaten Pati. 
Knowles, Malcolm S. (1970). The Modern Practice of Adult Education: Andagogy Versus Pedagogy. Chicago: Association Follett Publishing Company.

Mikkelsen, Britha, 2003. Methods for Development Work and Research: A Guide for Practitioners, Penerjemah: Matheos Nalle, Metode Penelitian Partisipatoris Dan Upaya-Upaya Pemberdayaan, Sebuah Buku Pegangan bagi Para Praktisi Lapangan, Jakarta: Yayasan Obor Indonesia.

Moleong, Lexy. 2000. Metodologi Penelitian Kualitatif. Bandung: PT. Remaja Rosda Karya.

Siswanto, Budi. 1998. Siasat Dan Kepentingan Perempuan Dalam Struktur Kekuasaan Keluarga Pedesaan, Studi Kasus Di Desa Lang-lang Kecamatan Singosari Kabupaten Dati II Malang. Jurnal Penelitian Ilmu-Ilmu Sosial. Volume 1 Th. 1998. Malang: Universitas Merdeka.

Sudjana, H.D. 1993. Metode dan Teknik Pembelajaran Partisipatif dalam Pendidikan Luar Sekolah. Bandung: Nusantara Press.

Sudjana, H.D. 2004. Manajemen Program Pendidikan Untuk Pendidikan Nonformal dan Pengembangan Sumber Daya Manusia. Cetakan Ketiga. Bandung: Falah Production.

Sugiyono, 2005. Memahami Penelitian Kualitatif. Bandung: CV. Afabeta.

Thamrin dan Sawedi Muhammad, 2002. Babak Baru Hubungan Negara Dengan Warga : NIlai Strategis Partisipasi Warga Menuju Local Good Governance (Perbandingan Beberapa Negara), Makalah, Dibawakan dalam Workshop Otonomi Daerah dan Akuntabilitas Publik dalam Perspektif Lokal, Jakarta: Kedeputian Ilmu Pengetahuan Sosial Kemanusiaan Lembaga Ilmu Pengetahuan Indonesia (IPSK-LIPI), Jakarta, 20 Agustus 2002.

Wildan Saugi dan Sumarno, 2015. Pemberdayaan Perempuan Melalui Pelatihan Pengolahan Bahan Pangan Lokal, Jurnal Pendidikan dan Pemberdayaan Masyarakat Volume 2 - Nomor 2, November 2015, (226 - 238) http://journal. uny.ac.id/ index. $\mathrm{php} / \mathrm{jppm}$, 